\title{
BRIEF DESCRIPTION OF THAI
}

The minimum words of the Thai language are predominately monosyllabic, but unanalyzable polysyllabic words also occur. Besides consonants and vowels, each syllable has one of five phonemically differentiated tones. Morphology is restricted to derivation since the language makes no use of inflection. In syntax the order of words is usually quite rigid though minor variations are occasionally permissible. Thai is like English in that the typical sentence contains subject, verb and object, in that order. But Thai attributive constructions differ from those of English in that the head must always precede the attribute. Additional features of Thai are described in the following paragraphs under the headings Phonemes, Derivation, and Syntax.

\section{PHONEMES}

\begin{tabular}{|c|c|c|c|c|c|c|}
\hline \multirow{3}{*}{ Stops: } & CONSONANTS: & Bilabial & Dental & Palatal & Velar & Glottal \\
\hline & Vd. Unasp. & b & d & & $-g$ & \\
\hline & Vl. Unasp. & p- & $t-$ & $c-$ & k- & $?$ \\
\hline & Vl. Asp. & ph- & th- & ch- & kh- & \\
\hline Spi rants: & Vl. Unasp. & $f-$ & s- & & & $h-$ \\
\hline Sonorants: & Vd. Semivowels & w & & $\mathrm{j}$ & & \\
\hline & Vd. Nasals & $\mathrm{m}$ & $\mathrm{n}$ & & $y$ & \\
\hline & Vd. Lateral & & $1-$ & & & \\
\hline & $\begin{array}{l}\text { Vd. Trill or } \\
\text { Retroflex }\end{array}$ & & $r-$ & & & \\
\hline
\end{tabular}

\section{Examples of Consonants}

บิน bin' to fly, สิบ sìb' ten, ดิน din' earth, เห็ด hèd' mushroom, นก nog' bird. ไป $\mathrm{paj}^{\prime}$ to go, ตาย taaj' to die, จริง $\mathrm{cing}^{\prime}$ to be true, กิน $\mathrm{kin}^{\prime}$ to eat, อิ่ม ' $\mathrm{im}$ ' to be full, แกะ kغे?' sheep.

ผ่าน phàan' to pass, ไทย thaj' Thai, ข้าง cháạ' elephant, ฆ่า khâ' to kill. ฟ้า fáa' sky, ขึ้อ sýy' to buy, ห้า hâa' five.

หมา $\mathrm{ma} \mathrm{a}^{\prime} \mathrm{dog}$, ตาม taam' to follow, นา naa' field, ร้าน ráan' store, งู guu' snake, ฟัง fay' to listen.

ลิง lin' monkey, รู้ rúu' to know.

Rare Anglicized finals: เอ็ข. 'éch' (the letter) H, เอ็ฟ. 'éf' F, ออฟฟิค 'śffís' office (also 'j́ffíd'), เลนซ์ lens'lens (also len'), ฟุตบอลล์ fúdbəol' football (also fúdbon').

VOWELS:

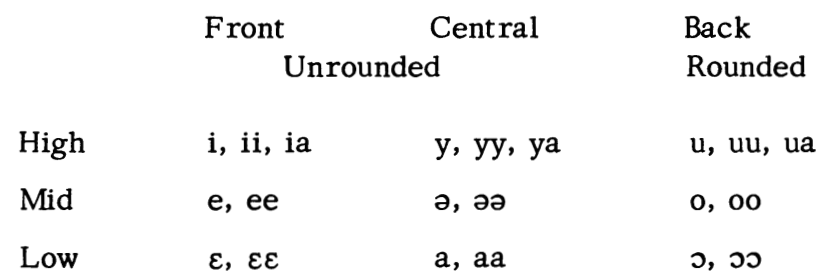




\section{Examples of Vowels}

ติ tì?' to criticize, ลิ้น $1 \mathrm{in}^{\prime}$ tongue, มี $\mathrm{mii}^{\prime}$ to have; there is, มีด mกid' knife, เลีย lia' to lick, เลียง słay' sound, (vocal) noise, tone (of the spoken language).

เตะ tè?' to kick, เล่น lên' to play, เท thee' to pour out, เหตุ hèed' reason.

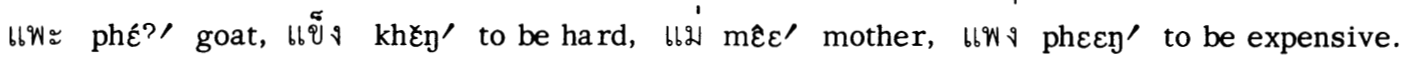

ครึ khrý?' to be old-fashioned, หนึ่ง nỳy' one, มือ myy' hand, พื้น phýyn' floor, เลือ sy̌a'

tiger, เมือง myay' town.

เยอะ jəว' to be a whole lot, เงิน gən' silver, money, เข่อ sริว' to be foolish, เนย nəวj' butter.

ค่ะ khâ' yes! (w.sp.), ปะ pà' to patch, พัด phád' to blow, มา maa' to come, หลาน

lăan' grandchild, niece, nephew.

ดุ dù?' to be fierce, หุง hŭy' to cook (rice), หมู mŭu' pig, ขูด khùud' to scrape, หัว hŭa' head, ควร khuan' ought to.

โต๊ tó? table, อด 'วd' to starve, โหล $1 \mathrm{do}^{\prime}$ dozen, โลก $100 \mathrm{og}$ ' world.

เพราะ phró?' because, ส่อง sว̀y' to shine, ห่อ hว̀ว package, สอง sวัวy' two.

TONES (in nonterminal position).

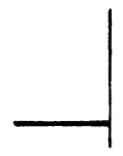

Middle

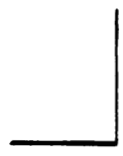

Low

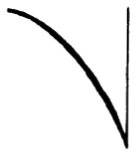

Falling

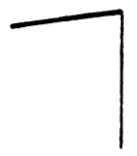

High

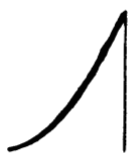

Rising

NOTE: The middle tone is shown by no mark, the low tone by ( $\left.{ }^{\prime}\right)$, the falling tone by $\left({ }^{\wedge}\right)$, the high tone by $\left({ }^{\prime}\right)$, and the rising tone by $\left({ }^{\prime}\right)$. Thai grammarians call the middle tone the "common" tone and refer to the low, falling, high, and rising tones as the 1st, 2nd, 3rd, and 4th tones respectively. This is in reference to the tones as sounds, not as written symbols.

\section{Examples of tones}

นา naa' field, น้อยหน่า nว́วjnàa' custard apple, หน้า nâa' face, น้า náa' maternal uncle or aunt (yg.), หนา năa' to be thick.

เผ็ด phèd' to be hot (peppery), เพขร phéd' diamond, หมาก màag' areca, มาก mâag' to be much. Rare: เถอะ thə?' [sic] imperative particle, ค่ะ khâ' yes (w.sp.), ขิชะ chíchá' interjection of contempt.

EMPHATIC TONES. Any of the five tones can be accompanied by the phoneme of emphasis. This is indicated by placing an exclamation point (!) in front of the syllable receiving this treatment. Such tones a re uttered at a higher pitch level than their corresponding normal tones and also have a somewhat "screechy" quality. They occur in exclamatory utterances. A high emphatic tone may replace any one of the five normal tones in emphatic repetitive expressions. 


\section{Examples of Emphatic Tones}

อุยตาย !?újtaaj'। exclamation expressing dismay, ข่วยด้วย châj!duaj'। Help! (an urgent call), ถุ !thǔj' imitative of a sound uttered to spurn someone. Emphatic repetitive expressions: ดี๊ดี !díidii' Very good! ร้อนๆ !róonróon' Frightfully hot! ย้ากยาก !jáagjâag' Terribly difficult! อิ๊มอิ่ม !? $1 \mathrm{~m}^{\text {? }}$ im $\mathrm{m}^{\prime}$ Awfully full! เค้มเค็ม !khémkhem' Terribly salty!

STRESS. This is marked by a heavy acute (' ) placed after any syllable which is uttered with full strength. All unmarked syllables are "reduced" in strength, i.e. are considerably shortened and weakened. The stress is not necessarily always placed on the same syllable. Sometimes the difference is simply a matter of free variation (or individual va riation) but at other times it implies a different connotation for the phrase. Each rhythm group has at least one stressed syllable. There is no spacing between the syllables of a single rhythm group, but when more than two stressed syllables occur within a rhythm group, a hyphen is used to indicate a slightly lesser amount of cohesion.

\section{Examples of Stress}

ภาษา phaasăa' language; นาวี naa'wii' navy; ไม่ดี mâjdii' not good, bad; เมื่อคืนนี้ mŷa khyyn'níi' last night; จะ ไปบ้าน capajbâan' will go home; เดือนมีนาคม dyanminaa'khom' March; ไม่เป็นตัวเป็นตน mâjpentua'penton' to be unformed, amorphous; ผู้โฆษณา phưkhô०= sanaa' advertiser; ไกลตาไกลใจ $\mathrm{klaj}^{\prime} \mathrm{taa}^{\prime}-\mathrm{klaj} \mathrm{caj}^{\prime}$ out of sight, out of mind.

ขาวบ้านร้านตลาด chaawbâan'-ráan'talàad' the whole neighborhood.

TERMINALS. There are three terminal markers to indicate the intonation of a phrase or sentence: the raised high in which the whole utterance is raised in pitch $(\uparrow)$, the sustained in which there is little if any drop in pitch before pause $(\rightarrow)$, and the falling or dropping intonation ( $\downarrow$ ). These markers are rarely needed in a dictionary since complete utterances a re entered only in the case of a few fixed phrases or in the illustrative material needed for some of the entries.

เอะ ยังไม่ไปโรงเรียนเรอะ !?é’ $\rightarrow$ jaymâjpaj'roọrian'rá $\uparrow$ Haven't (you) gone to school yet?

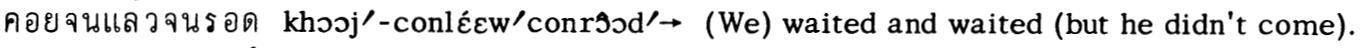
เราจะ ไปไหนก็ได้ rawcapajnaj/kß̂âaj! We can go anywhere we like.

\section{Permitted Initials}

Every syllable must begin in a consonant, but not more than two consonants a re permitted here. All single consonants shown in the chart on page xi with the exception of/-g/ may occur in initial position. Initial clusters begin in $/ \mathrm{p}, \mathrm{t}, \mathrm{k}, \mathrm{ph}, \mathrm{th}, \mathrm{kh} /$ followed by $/ \mathrm{l}, \mathrm{r}, \mathrm{w} / \mathrm{,} \mathrm{but}$ $/ \mathrm{t}, \mathrm{th} / \mathrm{are}$ followed only by /r/ and /w/ follows only / $\mathrm{k}, \mathrm{kh} /$.

CONSONANT CLUSTERS:

\begin{tabular}{|c|c|c|c|c|c|c|}
\hline & $\mathrm{p}$ & $t$ & $\mathrm{k}$ & ph & th & kh \\
\hline 1 & $\mathrm{pl}$ & & kl & phl & & khl \\
\hline$r$ & pr & $\mathrm{tr}$ & $\mathbf{k r}$ & $\mathrm{phr}$ & thr & khr \\
\hline$w$ & & & $\mathrm{kw}$ & & & khw \\
\hline
\end{tabular}


Examples of Consonant Clusters

ปล ใ plaa' fish, กลาง klaay' middle, เพลง phleey' song, คลอง khloon' canal. แปรง pre๕y' brush, ตรง troy' to be straight, กรง kroy' cage, พรม phrom' rug, ทฤษฎี thrísadii' theory, ครู khruu' teacher. The /tr/ cluster is relatively rare; /thr/ is extremely rare, perhaps limited to the example quoted.

กว่า kwàa' (more) than, ขวาน khwăan' ax.

\section{Permitted Finals}

The term "final" is used here in a special sense meaning the vowel plus the tone plus the final consonant if any. In other words it includes everything except the initial consonant or consonant cluster. Thai permitted finals are divided into two main types, (1) smooth and (2) stopped or abrupt, as described below.

TYPE I. SMOOTH FINALS (ON ALL FIVE TONES)

1. Doubled vowel or vowel cluster.

2. Short vowel, doubled vowel or vowel cluster $+/ m, n, y /$.

3. Short front vowel, doubled front vowel or $/ \mathrm{ia} /+/ \mathrm{w} /$.

4. Short back vowel, doubled back vowel or $/ \mathrm{ua} /+/ \mathrm{j} /$. Also $/ \mathrm{ya} /+/ \mathrm{j} /$ and very rarely $/ \mathrm{y} /$ or $/ \mathrm{yy} /+\mathrm{j} /$.

5. Mid and low central vowels $/ \partial$, əə, $a, a a /+/ j /$ or $/ w /$.

TYPE II. STOPPED OR SHORT FINALS (ON LOW, FALLING, HIGH, AND MID TONES)

6. Short vowel $+/ \mathrm{b}, \mathrm{d}, \mathrm{g}, ? /$ on low or high tone, ra rely falling tone. Very rarely short vowel

$+/ \rho /$ on mid tone. Occasionally short vowel on high or falling tone; or frequently on mid tone except before pause.

7. Doubled vowel or vowel cluster $+/ \mathrm{b}, \mathrm{d}, \mathrm{g} /$ on low or falling tone. Very rarely on high tone.

8. Vowel cluster $+/ P /$ on low or high tone, but this is extremely rare.

\section{Examples of Permitted Finals}

1. มี $\mathrm{mii}^{\prime}$ to have, เท thee' to pour out, แม่ $m \hat{\varepsilon} \varepsilon^{\prime}$ mother, ซื้อ sýy' to buy, เข่อ səəว to be foolish, ผ่า phà' to cut, slice, หมู mǔu' pig, โหล 1ชo' dozen, พ่อ phวิว' father, เมีย mia' wife, เมื่อ mya' when, ผัว phǔa' husband.

2. พิมพ์ phim' to print, เห็น hen' to see, ซึ่ง $s y^{\prime}$ which, ลง loy' to descend. คีม khiim' tongs, พื้น phýyn' floor, ของ khððว' thing.

เยี่ยม jกam' to visit, เพื่อน phyan' friend, ลวง luay' to deceive.

3. หิว hYw' to be hungry, เร็ว rew' to be fast, เลว leew' to be bad, เลี้ยว liaw' to turn.

4. คุย khuj' to chat, โดย dooj' by, คอย khวoj' to wait, สวย sǔaj' to be pretty, เหนื่อย nỳaj' to be tired. Rare: ฮี้ย, ฮี้ย !hýj', !hýyj' not so!

5. ไม่ไปไม่เปย mâjpaj'majpəj' won't go, เนย nəəj' butter, ไปเร็วไปเร็อว pajrew/pajrəw'

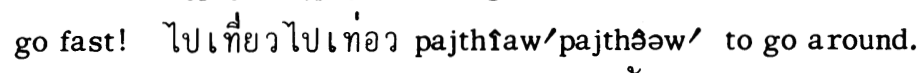

เรา raw' we, ราว raaw' about, เหล้า lâw' liquor, หนาว năaw' to be cold, ใส $\mathrm{săj}^{\prime}$ to be clear, สาย săaj' line. 
6. ขับ khàb' to drive, คับ kháb' to be tight; เผ็ด phèd' to be hot (peppery); เพขร phéd'

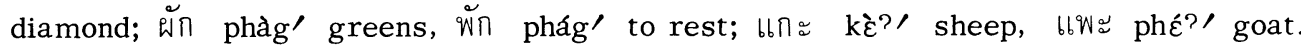
Rare: จั้ก câg' colloq. (rain) to fall. Very rare: เถอะ thə?' imperative particle. Short vowel without final stop: ขิขะ chíchá' interjection of contempt, คะ khâ' yes! (w. sp.), พิกล phîkon' to be strange, peculiar, สถิติ sathìtì? statistics, วนค่าสตร wanasàad' forestry, แตละประเทค่ tعlaprathêed' every single country.

7. หีบ hı̀ib' box, ลูบ laub' to stroke; เหตุ hèed' reason, เพค่ phêed' sex; หมาก màag' areca (nut), มาก mâag' to be much. Rare: โนด nóod' note [f. Eng.]

8. Rare: ผัวะเผียะ,พวัะเพี้ยะ phùa'phia?', phúa?phía? imit. of the sound of beating, slapping, cracking, ตามเดียะ taamdìa?' to follow closely, เจี๊ยะ cía?' slang to eat.

\section{DERIVATION}

The derivational processes used are compounding and reduplication, the former affecting verbs and nouns, the latter affecting verbs and imitative words.

\section{Compounding}

Common types of compounding resulting in verbs are listed and illustrated below:

1. Verb + noun: VERB

เข้าใจ khâwcaj' to understand: เข้า to enter + ใจ heart, spirit, mind.

ดีใจ diicaj' to be glad (to be heart-good): ดี to be good + ใจ .

ตั้งใจ tâncaj' to intend (to be heart-set): ตั้ง to set, place + ใจ.

ตั้งหน้า tânnâa' colloq. to be determined, intent: ตั้ง + หน้า face.

2. Noun + verb: VERB

ใจดี cajdii' to be good-natured (good-hearted) ใจ + ดี.

ใจเย็น cajjen' to be patient, cool-headed: ใจ + เย็น to be cool.

ใจกว้าง cajkwâay' to be generous: ใจ + กว้าง to be wide.

ใจร้อน cajróon' to be impatient, hot-headed: ใจ + ร้อน to be hot.

หูเบา hŭubaw' to be credulous (light-eared): หู ear + เบา to be light (in weight).

ใจเบา cajbaw' to be gullible (light-minded): ใจ + เบา.

หัวแข็ง hǔakhย̌ท' to be obstinate, hard-headed: หัว head + แข็ง to be hard.

ปากหวาน pàagwăn' to be suave, smooth-tongued: ปาก mouth + หวาน to be sweet.

คอหวาน khoวwăan' to have a sweet tooth (be sweet-necked): คอ neck + หวาน.

3. Verb + verb (coordinate compound): VERB

หุงต้ม hǔntôm' to cook (general term): หุง to cook (rice) + ต้ม to be boil (food).

สวยงาม sǔajnaam' to be beautiful: สวย to be pretty + งาม to be beautiful.

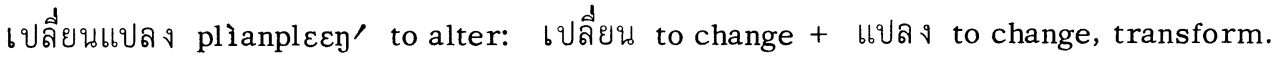

ขนล่ง khðnsòn' to transport: ขน to carry back and forth + ล่ง to send.

เปรี้ยวหวาน priawwăan' to be sweet and sour: เปรี้ยว to be sour + หวาน to be sweet.

ติดตั้ง tidtây' to install: ติด to connect, stick (to) + ตั้ง to set, place. 
Important types of compounding resulting in nouns include the following;

1. Noun + verb (head + attribute): NOUN

ของกิน khðo引kin' eatables, foodstuff: ของ thing, stuff + กิน to eat.

น้ำแข็ง námkhย̋’ ice: น้ำ water + แข็ง to be hard.

เงินสด yənsòd' cash: เงิน money, silver + ลด to be fresh.

เสื้อคลุม syakhlum' overcoat: เสื้อ coat + คลุม to cover over.

ผู้พิมพั phดuphim' publisher, printer: ผู้ person, one who + พิมพ์ to print.

ขู่างพิมพ์ châaphim' printer: ข่าง artisan, smith (bound stem, see pp. 142-3) + พิมพ์. ข่าวลือ khàalyy' rumor: ข่วว news + ลือ to be rumored.

โรงข่อม roonsภึวm repair shop: โรง building, structure (see p. 469) + ซ่อม to mend.

ที่แขวน thก̂ikhwย์ยn' peg or hook for hanging things: ที่ place + แขวน to hang.

คำนำ khamnam' preface (leading word): คำ word (see pp. 89-90) + นำ to lead.

ความโกรร khwaamkròod' anger: ความ state, condition (see pp. 81-2) + โกรธ to

be angry.

ความร้อน khwaamróon' heat: ความ + ร้อน to be hot.

การวิ่ง kaanwîn' running, the act of running: การ activity, -ing (see p. 29, mng. 3

and notes) + วิ่ง to run.

2. Noun + verb with object (head + attribute): NOUN

คนขายตั๋ว khonkhð̌ajtǔa' ticket seller (ticket-selling person): คน person, -er (see

pp. $73-4)+$ ขายตั๋ว to sell tickets: ขาย to sell, ตั๋ว ticket.

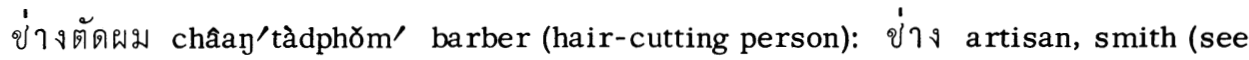

pp. 142-3) + ตัดผม to cut hair: ตัด to cut, ผม hair of the head.

ที่เขี่ยบุหรี่ thฬikhia/burì' ash tray (cigarette-flicking place): ที่ place + เขี่ยบุหรี่ to

flick (off ashes from) a cigarette: เขี่ย to flick, บุหรี่ cigarette.

เครื่องขักผ้า khryanságphâa' washer, washing machine (clothes-washing apparatus):

เครื่อง gear, apparatus, implement (see pp. 97-8) + ขักผ้า to wash cloth: ขัก to

wash, ผา cloth.

3. Noun + noun (head + attribute): NOUN

รถไฟ ródfaj' train: รถ vehicle, car + ไฟ fire.

ไฟฟ้า fajfáa' electricity: ไฟ fire + ฟ้า fáa' sky.

ขนตา khøntaa' eyelashes: ขน hair (except of the head) + ตา eye.

การเมือง kaanmyay' politics (country affairs): การ affairs of, matters of (see p. 29, mng. 2) + เมือง country (nation); town.

เครื่องมือ khryanmyy' tool: เครื่อง apparatus, implement (see pp. 97-8) + มือ hand.

คนกระเป๋า khonkrapåw' fare collector (purse-person): คน person, -er (see pp. 73-4)

+ กระเป๋า purse.

ช่างทอง châanthวoท' goldsmith: ช่าง artisan, smith (see pp. 142-3) + ทอง gold.

ขาวเมือง chaawmyay' native, native inhabitant; townspeople: ข่าว inhabitant of,

dweller in (see pp. 146-7) + เมือง country (nation); town. 
4. Noun + noun (coordinate compound): NOUN พ่อแม่ phวิวmยิย' parents: พ่อ father + แม่ mother. พี่น้อง phกิinว์ว ${ }^{\prime}$ brothers and sisters: พี่ older sibling + น้อง younger sibling. ผัวเมีย phŭamia' married couple: ผัว husband + เมีย wife. ลูกหลาน lauglăan' descendants: ลูก child + หลาน grandchild. ปู่ย่าตายาย pùuâa'taajaaj' ancestors: ปู่ย่า paternal grandparents ( ปู่ paternal grandfather, ย่า paternal grandmother) + ตายาย maternal grandparents (ตา maternal grandfather, ยาย maternal grandmother). This example is a secondary coordinate cpd. pleasingly welded together by the rhyme that exists between the second part of the first primary coordinate and the first part of the second primary coordinate.

แขนขา khย̌ยnkhăa' (the four) limbs: แขน arm + ขา leg.

เลื้อผ้า sŷaphå' clothing: เสื้อ coat, upper garment + ผ้า cloth, lower garment.

วัวควาย wuakhwaaj' livestock (in general): วัว cattle + ควาย water buffalo.

เป็ดไก่ pèdkàj' barnyard fowl (collectively): เป็ด duck + ไก่ chicken.

มีดพร้า mกidphráa' knives (of all kinds): มีด knife + พร้า jungle knife, kris.

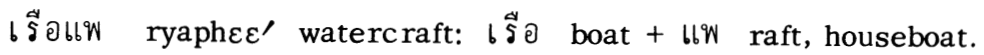

ภาษีอากร phaasYi'?aakıon' (all kinds of) government revenue: ภาษี taxes + อากร revenue.

\section{Elaborate Expressions}

Elaborate expressions are usually colloquial but a few are considered elegant. They are frequently based on compounds of the types illustrated above and are expanded by repeating a part of the compound and adding a new part, by inserting a syllable for the sake of rhyme, or by inserting a syllable which has some vague semantic relation to one of the original parts. Most of these expressions are made up of four parts. The semirepeated expressions have the same item as the first and third or as the second and fourth part. The expressions that are characterized by rhyme always show internal rhyme (i.e. the rhyming of adjacent syllables) between the second and third parts. The rhyming part is the one in second position and may be an item which (1) has no meaning and therefore functions only as a rhyme, (2) has a meaning inconsistent with the rest of the expression and again functions only as a rhyme, or (3) has a meaning of greater or less consistency with the rest of the expression and also rhymes. Those expressions which insert a part which has a vague semantic relation to one of the parts of the original expression often place it in second or fourth position. A variety of examples a re shown below.

หยิบเล็กหยิบน้อย jiblég'jìbnว่ว' elab. colloq. to pilfer: หยิบ to pick up, take up (in the hand), เล็กน้อย a little bit: เล็ก to be little, small, น้อย to be little, lesser. The word หยิบ is repeated and its second occurrence splits the coordinate เล็กน้อย .

รวบหัวรวบหาง raabhŭa'raabhăy' idiom. to gather everything together; to sum everything up: รวบ to gather together, หัว head, หาง tail. 
ร้อนอกร้อนใจ róon'dg'rósncaj' elab. colloq. to be worried, anxious: ร้อนใจ to be worried, anxious: ร้อน to be hot, ใจ heart, spirit, mind. The word en chest is often paired with ใจ in expressions like this, but ร้อนอก is not used alone. เดือดเนื้อร้อนใจ dỳadnýa'róoncaj' elab. colloq. to worry, be upset. Cf. เดือดร้อน dỳadrósn' to worry, feel anxious: เดือด to boil (of water), ร้อน to be hot, and ร้อนใจ to be worried, anxious (as in the preceding example). เนื้อ flesh, meat is added for balance and because of its vague semantic relation to ใจ. ลืมหูลืมตา lyymhŭu'lyymtaa' ela b. colloq. to open one's eyes to what is going on a round one. Cf. ลืมตา lyymtaa' to open the eyes: ลืม to open (eyes only), ตา eye. หู ear is often paired with ตา eye because of its vague semantic relation. หูป่าตาเถื่อน hŭupà'taathỳan' ela b. colloq. to be ignorant of what is going on. Here หู ear and ตา eye are paired as above, and ป่า forest and เถื่อน forest are likewise paired. The expression is welded together by the rhyming of ป่า and ตา. หุงหาอาหาร hŭghă'?aahăan' elab. eleg. to cook, prepare food: หุง to cook (rice),

หา to look for, อาหาร eleg. food. หา rhymes with the first part of อาหาร. เก็บหอมรอมริบ kèbhวom'roomríb' elab. colloq. to save up: เก็บ to pick up, collect, หอม (no mng., for rhyme only), รอม to save, ริบ (no mng.). ผู้หลักผู้ใหญ่ phaulàg'phaujaj' elab. colloq. (one's) superiors, elders. Cf. ผู้ใหญ่ phaujaj' superior, elder; adult: ผู้ person (in cpds.), ใหญ่ to be great. The expression is elaborated by repeating ผู้ and adding หลัก basis, principle, the latter word having at best only a vague semantic connection with the whole expression. น้ำหูน้ำตา tears, occurring in the phrase น้ำหูน้ำตาไหล námhǔu'námtaa'-lăj' elab. colloq. to cry, shed tears. Cf. น้ำตา námtaa' tears: น้ำ water, ตา eye.

The word น้ำ is repeated and หู ear is paired with ตา to form the elaboration. หมูเห็ดเป็ด ไก่ mǔuhèd'pèdkàj' colloq. meats of various kinds: หมู pig, เห็ด (inserted to rhyme with เป็ด ; otherwise means "mushroom"), เป็ด duck, ไก่ chicken.

\section{Reduplication}

Simple reduplication is used to form many imitative words, such as แค้ก ๆ khégkhég' i mit. of the sound of coughing, แฉง ๆ chènchغ̀y' i mit. of a clattering sound. There a re also other kinds of reduplication including several interesting types of ablauting reduplication. Some of these are listed and illustrated below.

1. A back vowel alternates with its corresponding front vowel:

u and $\mathrm{i}$ : ยุ่งยิ่ง jâjîn' to be confused, confusing, entangled (cf. ยุ่ง idem); จูจี้ cauçi $\mathrm{i}^{\prime}$ to be fussy, particular; ซุบซิบ súbsíb' to whisper; งัวเงีย yuania' to feel drowsy. o and e: โขเข soosee' to stagger; โหรงเหรง rðonrěey' to be sparse, few; โพล้เพล้ phl6o= phlée' twilight; โยกเยก jø̂ogjêeg' to oscillate (cf. โยก idem).

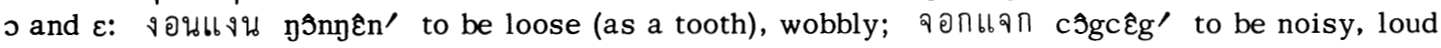

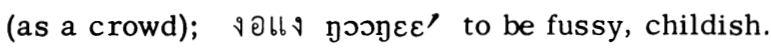




\section{Any vowel may alternate with a:}

i and a: ขิขะ chíchá' interjection of contempt; ขิงขัง chinchan' to hate, abhor, detest (cf. ขัง to hate, detest); วี้ดว้าด wíidwáad' to scream, screech (of women).

ia and aa: เกรียวกราว kriawkraaw' noisy, noisily.

e and a: เปล่งปลั่ง plèmplày' to glow (with health), be radiant (of looks); เคว้งคว้าง khwéey= khwáay' to be adrift; aimlessly; เกงกาง kêenkâay' to be gangly, awkward.

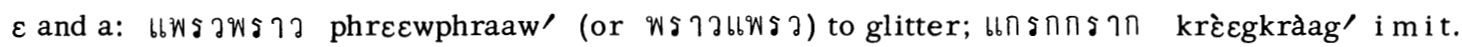

of a rustling sound.

y and a: พึมพัม phympham' mutteringly; งึมงำ nymnam' in murmurs; อึดอัด 'ỳd?àd' to

feel constricted, hemmed in; อืดอาด วỳyd?àad' to be slow, inert.

ya and aa: เหนื่อยหน่าย nỳajnàaj' listlessly (cf. เหนื่อย nỳaj' to be tired).

ว and a: เงอะงะ ฤว์?yá?' to be awkward, maladroit, inept; เหนอะหนะ nว̀?nà?' to be sticky;

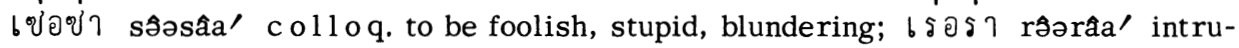

sively.

$\mathrm{u}$ and a: ผลุนผลัน phlǔnphlăn' hastily, precipitately; รุงรัง ruyray' to be untidy, messy; ซู่ซ่า

suusâa' roaringly (of water); มูมมาม muummaam' to be slovenly in manner of eating ua and aa: พรวดพราด phraadphrâad' abruptly, precipitately (cf. พรวด idem).

o and a: โปรยปราย proojpraaj' to scatter, sow, disseminate; โขยข่าย choojchaaj' to blow gently

(of the wind); โครกคราก khrôogkhrâag' i mit. sound of snoring, heavy breathing.

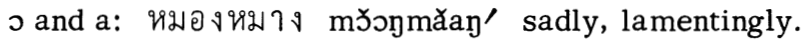

3. There are also other miscellanepus vowel alternations:

a and $e:$ ฮ.าเฮ haahee' i mit. sound of hearty laughter. Also เฮฮา.

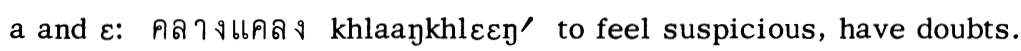

$\mathrm{i}$ and $\varepsilon$ : ยิ้มแย้ม $\mathrm{j} \mathrm{rmj} \varepsilon \varepsilon \mathrm{m}^{\prime}$ to be bright and smiling. Also แย้มยิ้ม.

ə and $\varepsilon:$ เยอะแยะ j子?j\{์?/ to be plentiful, a lot of, a multitude of (cf. แยะ and เยอะ idem);

เฉอะแฉะ chว?chغ̀?' to be wet, slushy.

o and o: ตรมตรอม tromtroom' sadly, forlornly. Also ตรอมตรม.

$\partial$ and $\mathrm{s}$ : เออออ ?วə?วо' colloq. to agree.

4. A change in vowel quantity with or without a change in vowel quality:

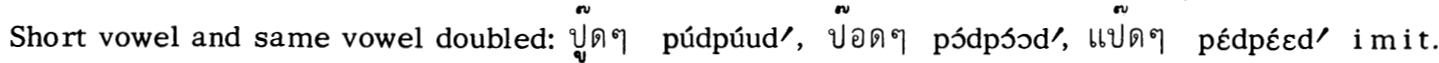

sound of car horn honking. (The short vowel is not reflected in the Thai spelling.)

Short vowel and different vowel doubled: วัง เวง wayween' to be lonely and desolate; อิดออด

'Id'วod' to demonstrate unwillingness or half-heartedness; อุ้ยอ้าย ว $\mathfrak{j}^{\mathrm{j}} \mathrm{a} a \mathrm{aj}$ ' to be ponderous and slow-moving; สุร่ยสุร่าย surajsurâa' to be a spendthrift, wasteful; ยุมย่าม jamjâam' meddlesomely; ลนลาน lonlaan' excitedly and precipitately.

5. A change in tone is always accompanied by other changes:

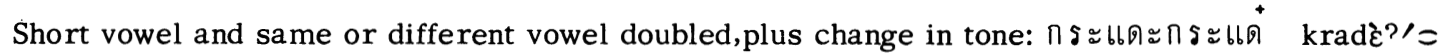

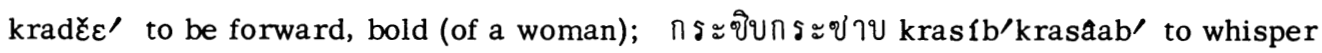
(cf. กระขิบ idem). วับวาบ wábwâab' to flicker, flickeringly. 


\section{SYNTAX}

The typical sentence contains subject, verb, object, in that order, e.g. เขาซื้อ เนื้อ kháw ${ }^{1}$ sýy $^{2}{ }_{\text {nýa }}{ }^{3}$ \ $\mathrm{He}^{1}$ buys ${ }^{2}$ meat.

However, certain types of subjectless sentences are also used, e.g.

มีคนมากที่นี่ $\mathrm{mii}^{1} \mathrm{khon}^{\prime}{ }^{2} \mathrm{maag}^{\prime}{ }^{3}$-thrinกii ${ }^{4} \downarrow$ There are ${ }^{1}$ lots of ${ }^{3}$ people ${ }^{2}$ here.

Pronouns are generally omitted if they are implied in the linguistic or situational context, e.g. ไปไหน paj $^{\prime}{ }_{\text {naj }} \prime^{2}$ । Where ${ }^{2}$ are (you) going ${ }^{1}$ ? (said upon meeting a friend).

The nucleus of the predicate is usually a verb, as shown in the examples above, but there is an important type of verbless predication in which a demonstrative pronoun occupies either the subject or predicate position, e.g.

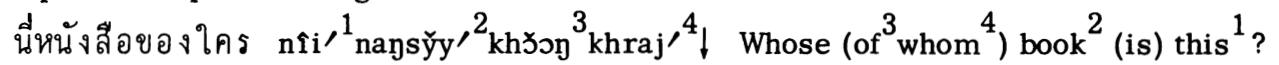
นั้นอะไร nân ${ }^{1}{ }^{2} \mathrm{araj}^{2}{ }^{2} \downarrow$ What ${ }^{2}\left(\right.$ 's) that ${ }^{1}$ ?

ใครนี่นะ $\mathrm{khraj}^{1}{ }_{\mathrm{nIi}}{ }^{2}{ }_{\mathrm{na}}{ }^{3}$ เ $\mathrm{Now}^{3}$ who ${ }^{1}$ ('s) this ${ }^{2}$ ?

Obligatory categories of tense and number do not exist, and a sentence like ม้าวิ่งเร็ว máa ${ }^{1}=$ win ${ }^{2}$ rew ${ }^{3} \downarrow$ may mean "The horse ${ }^{1}$ runs $^{2}$ fast," "The horses run fast," "Horses run fast," or "The horse(s) ran fast." But time and number may be shown by special words when needed.

The word classes are nouns $(\mathrm{N})$, numerals $(\mathrm{Nm})$, classifiers $(\mathrm{C})$, demonstrative adjectives $(\mathrm{dA})$, interrogative-indefinite adjectives (iA), demonstrative pronouns (dP), interrogativeindefinite pronouns (iP), personal pronouns $(\mathrm{P})$, verbs $(\mathrm{V})$, adverb-auxiliaries (AA), prepositions $(\mathrm{Pp})$, conjunctions $(\mathrm{Cj})$, particles $(\mathrm{Pt})$, and exclamatives $(\mathrm{E})$. Before illustrating some of these classes, it is important to point out that words corresponding to adjectives and adverbs in English are true verbs in Thai. Consequently a word like ดี dii' means "is good; good; well" and is used in the following ways: (1) as the nucleus of a predication, e.g.

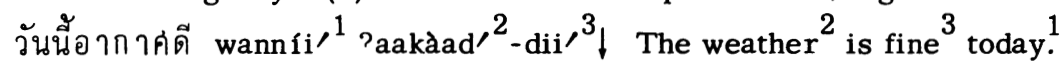

(2) as the modifier of a noun, e.g.

เขาเป็นคนดี kháw ${ }^{1}$ pen $^{\prime 2}$ khon $^{3} \mathrm{dii}^{\prime}{ }^{4} \downarrow \mathrm{He}^{1}$ is $^{2}$ a good ${ }^{4}$ person.

(3) as the modifier of another verb, e.g.

เขาพูดภาษา ไทย ได้ดี kháw ${ }^{1}$ phaud ${ }^{2}{ }_{\text {phaasăathaj }}{ }^{3} \mathrm{daj}^{4} \mathrm{dii}^{\prime}{ }^{5} \downarrow$ He $\mathrm{Hean}^{1}{ }_{\text {speak }}{ }^{2}$ Thai $^{3}$ well. ${ }^{5}$

Nouns may be used alone or serve as the head in noun-phrases containing head plus attribute, in that order. The attribute may be simple, e.g. another noun, a personal pronoun, a verb, or a demonstrative adjective. However, it is often complex, e.g. a preposition + noun or pronoun, a numeral +classifier, a classifier + verb, a classifier + demons. or interrog. -indef. adjective, a numeral + classifier + demons. or interrog. -indef. adjective, a verb + classifier + demonstrative adjective, a relative clause, or a classifier + relative clause. A few examples: พ่อผม phวิ ${ }^{\prime}$ phðm $^{2}$ (noun, personal pronoun) my (m. sp.) ${ }^{2}$ father.

คนดี khon ${ }^{1} \mathrm{dii}^{\prime}{ }^{2}$ (noun, verb) a good ${ }^{2}$ person.

ส้มนี้ $\mathrm{sôm}^{1}{ }^{1} \mathrm{ni \textrm {i }}^{2}{ }^{2}$ [nî sic] (noun, demons. adj.) this ${ }^{2}$ orange.

แม่ของเขา $\mathrm{m \varepsilon ิ}^{\prime}{ }^{1} \mathrm{kh}{ }^{2}{ }^{2} \mathrm{kháw}^{\prime}{ }^{3}$ (noun, prepos., pers. pron.) his (of ${ }^{2}$ him $^{3}$ ) mother. นักเรียนสามคน nágrian ${ }^{1}$-săam ${ }^{2}$ khon $^{3}$ (noun, num., clf.) three ${ }^{2,3}$ students. 
นักเรียนคนนี้ nágrian ${ }^{1}$ khon $^{2}{ }_{n \in i}{ }^{3}$ (noun, clf., demons. adj.) this ${ }^{2,3}$ student. ${ }^{1}$ นัก เรียนคนไหน nágrian ${ }^{1}$ khon $^{2}{ }_{\text {naj }}{ }^{3}$ (noun., clf., interrog.-indef. adj.) which ${ }^{2,3}$ student. นักเรียนสามคนนี้ nágrian ${ }^{1}$-săam ${ }^{2}{ }^{2}$ khon $^{3}{ }_{n \rightarrow i}{ }^{4}$ (noun, num., clf., demons. adj.) these ${ }^{3,4}$ three $^{2,3}$ students.

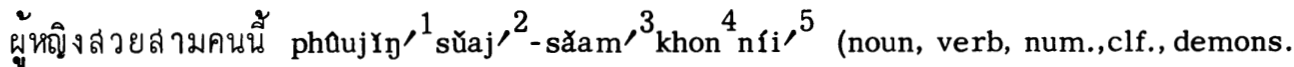
adj.) these ${ }^{4,5}$ three $^{3,4}$ pretty $^{2}$ women.

ผู้หญิงที่ขื้อของ phaujYy ${ }^{1}{ }^{- \text {thri }^{2}}{ }^{2}$ sýy $^{\prime}{ }^{3}$ khðoy $^{\prime}{ }^{4}$ (noun + rel. cl.) women ${ }^{1}$ who ${ }^{2}$ shop. ${ }^{3,4}$

The principal uses of numerals, classifiers, and demonstrative and interrogative-indefinite adjectives are illustrated above. It is important to observe that the choice of classifier is determined by the noun-head. Thus คน khon' is the ordinary classifier for people: ตัว tua' for animals (and also for tables, chairs, playing cards); ลำ lam' for boats; คัน khan' for vehicles (except carts); เล่ม lêm' for sharp-pointed objects, such as knives, and for carts, books, etc.; and many others. In addition to the types of classifiers just mentioned there are also classifiers denoting times or occasions, periods of time, units of money and other types of measurement. These are often used in attributive phrases without expressed noun-head, e.g.

คราวนี้ khraaw ${ }^{1}{ }_{n i \mathrm{i}}{ }^{2}$ (clf., demons. adj.) this ${ }^{2}$ time ${ }^{1}$ (occasion). ลองวัน $\operatorname{s\zeta oy~}^{1}$ wan $^{2}$ (num., clf.) two ${ }^{1}$ days. ห้าบาทห้าสิบสตางค์ hâa ${ }^{1}$ bàad $^{\prime 2}$-hâasib ${ }^{3}$ satay $^{\prime 4}$ (num., clf.; num., clf.) five ${ }^{1}$ bahts ${ }^{2}$

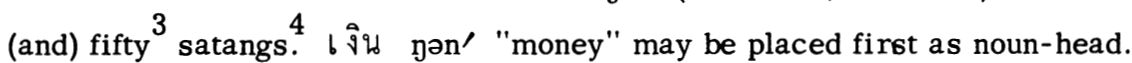

Personal pronouns may be substituted for nouns but they are not followed by as many types of attributes. Such pronouns a re differentiated not only for person and sometimes number but also for relative social status and occasionally for sex. Deferential first person terms differentiated for sex are ผม phðm’ I (m.sp.) and ดิฉัน dichán' I (w.sp.). Pronouns differentiated on the status level often have paired terms for "I" and "you", e.g.

ผม phชm' I (m.sp.) or ดิฉัน dichán' I (w.sp.) paired with คุณ khun' you. These a re deferential terms used among equals or when speaking to superiors.

ฉัน chán' I (m. or w.sp.) paired with เธอ thəə’ you. Used when speaking to intimates or inferiors, hence often to children.

กัน $\mathrm{kan}^{\prime} \mathrm{I}$ (m. sp. to m.) paired with แก $k \varepsilon \varepsilon^{\prime}$ you. Used among intimates of the same sex, otherwise insulting.

Third person pronouns a re also differentiated for social status, ra rely for number, and still more rarely for sex. Some of the most common of these are the following:

แก $k \varepsilon \varepsilon^{\prime}$ he, she, they. Common respectful term.

เขา kháw' he, she, they. General term.

มัน man' he, she, it, they. A derogatory term when used of people, the common term when speaking of animals (and occasionally of things; see p. 397).

หลอน lı̀n' she. Of frequent use in the written language.

There is also a first person plural pronoun เรา raw' used as the common term for "we." In addition it is sometimes used to mean "I" when speaking to oneself or to intimates and inferiors. 
Most kinship terms also have as one of their uses a pronominal one. Thus พ่อ phวิว' "father" may be used to mean "you, he, Father" (sp. to or of one's father) or "I, Father" (father sp. to child); see p. 366. Similar extensions of usage characterize แม่ mह̂े' mother, p. 410; พื่ phî' older sibling, p. 372; น้อง nón' younger sibling, p. 257, and many others.

Verbs have two main functions, in one of which they are called "primary verbs" (V), in the other "secondary verbs" (sV). Primary verbs function as the nucleus of a predication and are translated by English verbs. Secondary verbs, on the other hand, resemble English adverbs if intransitive, English prepositions if transitive. Examples:
น้ำลง náam ${ }^{1} \log ^{\prime}{ }^{2} \downarrow$ The water ${ }^{1}$ recedes. ( ลง to descend, recede, prim. v.) นั้งลงเถอะ nây ${ }^{1} \log ^{2}$ thə? ${ }^{3}{ }^{3} \mathrm{Sit}^{1}$ down! ${ }^{2,3}$ (นั้ง to sit, prim. v.; ลง down, sec. v.) เขาเป็นครู $\mathrm{khá}^{1} \mathrm{pen}^{2} \mathrm{khruu}^{3}{ }^{3} \mathrm{He}^{1}$ is $^{2}$ a teacher. (เป็น to be ..., prim. v.) เขากินไข่เป็นอาหาร เข้า kháw ${ }^{1}$ kin $^{2} \mathrm{khàj}^{\prime}{ }^{3}$ pen $^{4}$ ?aahăancháaw ${ }^{5} \downarrow \mathrm{He}^{1}$ eats $^{2}$ eggs $^{3}$ for ${ }^{4}$
breakfast. (กิน to eat ..., prim. v.; เป็น for, as ..., sec. v.)

Adverb-auxiliaries are a class of words, some of which are translated by English auxiliary verbs and others by English adverbs. All belong to a single class in Thai and are identified as such by their fixed position with respect to the subject (which they follow) and to the nuclear verb (which they precede), e.g. ต้อง t3̂y' "must" in

เขาต้องไปบ้าน kháw ${ }^{1} \mathfrak{y}^{\prime}{ }^{\prime}{ }^{2} \mathrm{paj}^{3}$ bâan $^{\prime} \downarrow \mathrm{He}^{1}$ must ${ }^{2}$ go ${ }^{3}$ home.

Other important adverb-auxiliaries include the following: จะ ca= "shall, will," ควร khuan' or ควรจะ khuan'ca= "ought to," เห็นจะ hẻnca= "seemingly, seems to," ไม่ mâj', mâj= "not, ยัง jay' "still, yet," จึง cyy' "consequently." More than one adverb-auxiliary may be used in the same sentence and in this event their relative order is fixed. Examples:

เขาจะไม่ไปบ้าน $\mathrm{kháw}^{1} \mathrm{ca}^{2} \mathrm{maj}^{3} \mathrm{paj}^{4} \mathrm{baan}^{5}{ }^{5} \mathrm{He}^{1}$ will $^{2}$ not $^{3}$ go ${ }^{4}$ home.

เขายังอยู่บ้าน kháw ${ }^{1}$ jan $^{2}$ jùu ${ }^{3}{ }^{3}$ âan $^{\prime}{ }^{4}+\mathrm{He}^{1}$ is $^{3}$ still $^{2}$ at home.

เขายังไม่ไปบ้าน kháw ${ }^{1} \mathrm{jag}^{2} \mathrm{maj}^{\prime}{ }^{3}{ }_{\mathrm{paj}}{ }^{4} \mathrm{banan}^{\prime}{ }^{5} \mathrm{He}^{1}$ hasn't ${ }^{3}$ gone ${ }^{4}$ home ${ }^{5}$ yet. $^{2}$

Conjunctions are used to connect sentences or clauses and they precede everything else: เมื่อเขาไปบ้าน mya ${ }^{1} \mathrm{kháw}^{\prime 2} \mathrm{paj}^{3} \mathrm{baann}^{\prime}{ }^{4} \rightarrow$ when ${ }^{1}$ he ${ }^{2}$ went ${ }^{3}$ home. ถ้าผมไม่อยู่บ้าน thâa ${ }^{1} \mathrm{phrm}^{\prime}{ }^{2}$ mâj ${ }^{3}$ jùu ${ }^{4}$ bâan ${ }^{5} \rightarrow$ if $^{1} \mathrm{I}^{2}$ am $^{4}$ not $^{3}$ at home.

Particles are sentence-ending words and fall into two classes, those indicating mode and those connoting the social status and sometimes the sex of the speaker. Modal particles include question, imperative, and other particles (first two examples below). Status particles include ครับ khráb' (deferential m.sp.), ค่ะ khá, คะ khá' (deferential w.sp.), and จ้ะ cá, จะ cá (m. or w. sp. to intimates or inferiors, including children). Status particles always follow other particles, e.g.

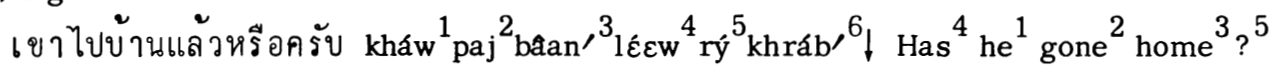
ตื่นเ ถอะ tỳyn ${ }^{1}$ thə? ${ }^{2} \downarrow$ Wake up ${ }^{1}{ }^{2}$ ( เ ถอะ imperative part.) ขอบคุณคะ $\mathrm{kh \jmath \supset bkhun}{ }^{1} \mathrm{kha}^{\prime}{ }^{2} \downarrow \mathrm{Thanks}^{1}$ (w. sp. ${ }^{2}$ ).

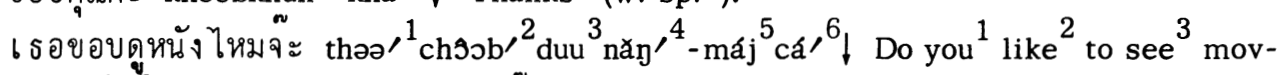
ies ${ }^{4}{ }^{5}$ (ไหม question part., จะ status part. used with intimates, children). 


\section{SOME REFERENCES ON THE THAI LANGUAGE}

\section{TEXTBOOKS AND DICTIONARIES}

Bhaopichitr, Dr. Kamol. Modern English-Thai Dictiona ry. Bangkok, B. E. 2492 (1949). 819 pp.

-... Modern Thai-English Dictionary. Bangkok, B. E. 2498 (1955). 765 pp.

Haas, Mary R. Thai Reader. American Council of Learned Societies, Washington, D. C., 1954. Pp. 1-215.

..... Thai Vocabula ry. American Council of Learned Societies, Washington, D.C., 1955. Pp. 217-589.

-.... The Thai System of Writing. American Council of Learned Societies, Washington, D. C., 1956.115 pp.

Haas, Mary R., and Heng R. Subhanka. Spoken Tha i, Books I and II. Henry Holt and Co., New York, 1946-48. $701 \mathrm{pp}$.

Jamsai, M. L. Manich. English-Thai Dictionary. 8th printing, Bangkok, B. E. 2490 (1947). $610 \mathrm{pp}$.

-...- Thai-English Dictionary. 3rd rev. ed., Bangkok, 1949. 692 pp.

McFarland, G. B. Thai-English Dictionary. Stanford University Press, second printing, 1954. $1019 \mathrm{pp}$.

Phloyphrom, Plang. Pru's Standard Thai-English Dictionary. Bangkok, 1955. $1774 \mathrm{pp}$.

Sreshthaputra, So, ed. The New Model English-Thai Dictionary. Bangkok, 1940. 3 vols., 4000 pp.

Thai-Thai Dictiona ry. Ministry of Education, Bangkok, B. E. 2493 (1950). 1057 pp.

\section{ARTICLES AND MONOGRAPHS}

Abramson, Arthur S. The Vowels and Tones of Standard Thai: Acoustical Measurements and Experiments. Publication Twenty of the Indiana University Research Center in Anthropology, Folklore, and Linguistics. Bloomington, 1962.

Egerod, Soren. "Swatow Loan Words in Siamese." Acta Orientalia, vol. XXIII (1958-59), pp. $137-156$.

Fowler, Murray, and Tasniya Isarasena. The Total Distribution of the Sounds of S i a mes e. University of Wisconsin Press, Madison, 1952. 8 pp. + 4 microcards.

Haas, Mary R. "Techniques of Intensifying in Thai." Word, vol. II (1946), pp. 125-130.

-..-.. "Types of Reduplication in Thai." Studies in Linguistics, vol. I (1942), no. 1, pp. $1-6$.

-... "The Use of Numeral Classifiers in Thai. "Language, vol. XVIII (1942), pp. 201-205.

Henderson, Eugenie J. A. "Prosodies in Siamese: a Study in Synthesis." A sia Major n.s., vol. I (1949).

Noss, Richard B. Thai Reference Grammar. Washington, D. C. 1964. 